\title{
Degradation of Agar by a Gram-negative Bacterium
}

\author{
By B. v. HOFSTEN AND M. MALMQVIST \\ Institute of Biochemistry, University of Uppsala, \\ $S$-75I 2 I Uppsala, Sweden
}

(Received 23 April 1974; revised 14 October 1974)

SUMMARY

An agar-degrading bacterium, having a guanine-cytosine content of $50 \cdot 5 \mathrm{~mol} \%$ has been isolated from sewage. This Gram-negative rod grew well in a simple salts medium containing various carbohydrates.

Growing bacteria dissolved gels and suspensions of agar and agarose rapidly, but did not attack cross-linked agars. Agarase was cell-bound in exponentially growing cultures but was released into the medium at stationary phase. Both cell extracts and culture filtrates released reducing sugars from agar solutions and prevented them from gelling. Gels were not dissolved by enzyme solutions, but the turbidity and iodine-binding properties of the agar were decreased.

\section{INTRODUCTION}

Agar is the trivial name for a complex group of gel-forming polysaccharides derived from red algae. It can be fractionated into components which differ in molecular weight, charge and gelling properties (Duckworth \& Yaphe, 1971 $a$; Izumi, 1972). All these components are composed mainly of alternating residues of 3 -linked $\beta$-D-galactopyranose and 4 -linked 3,6-anhydro- $\alpha$-L-galactopyranose residues. The essentially neutral components of agar are called agarose; other fractions contain sulphate and pyruvate residues in varying amounts.

Agar is widely employed as a gelling agent in the preparation of microbiological culture media, and agarose is much used as an anticonvection agent in electrophoresis and diffusion experiments. Recently, agarose has also found many applications in gel chromatography and as a matrix for covalent attachment of enzymes and other compounds. It would sometimes be useful to have enzymes which could degrade agar gels or suspensions, and this was one reason why we became interested in agarolytic bacteria.

Several groups of bacteria can degrade agar (Araki \& Arai, 1954; Sampietro \& Vettuone de Sampietro, 197I), and some agarases which hydrolyse specific residues have been partially purified and used in studies of the structure of agar (Araki \& Arai, 1956; Duckworth \& Yaphe, 197I $b$ ). It appears, however, that these enzymes have only a slight effect on gels. Why purified enzyme cannot hydrolyse gels is not clear.

We have isolated a bacterium which is unusually effective in degrading agar and agarose, and some of the properties of this organism are described. Enzyme extracted from the organism or found in the medium after growth is very effective in degrading agar solutions, whereas gels and agar suspensions are more resistant. 


\section{METHODS}

Bacterial strain. An enrichment culture containing agar-degrading bacteria was obtained by inoculating a salts solution (medium $\mathrm{B}$, see below) containing $0.2 \%$ agar with water from the local sewage treatment plant. A pure culture was isolated by repeated streakings on plates with the same medium solidified with $\mathrm{I} .5 \%$ agar. Large holes were formed in such agar plates (Fig. 2 below). The bacterium has been maintained by regular transfers on agar plates. It has been deposited in the National Collection of Marine Bacteria, Torry Research Station, Aberdeen, Scotland, as NCMBI9I4. The guanine-cytosine content was $50.5 \mathrm{~mol} \%$ as determined by Dr D. M. Gibson.

Salts medium and cultivation. The basal salts solution (medium B) used in most experiments, contained ( $\mathrm{g} / \mathrm{l}$ distilled water): $\mathrm{NaNO}_{3}, 2 ; \mathrm{K}_{2} \mathrm{HPO}_{4}, 0.5 ; \mathrm{MgSO}_{4} \cdot 7 \mathrm{H}_{2} \mathrm{O}, 0.2$; $\mathrm{CaCl}_{2} .2 \mathrm{H}_{2} \mathrm{O}, 0.02 ; \mathrm{MnSO}_{4} . \mathrm{H}_{2} \mathrm{O}, 0.02 ; \mathrm{FeSO}_{4} \cdot 7 \mathrm{H}_{2} \mathrm{O}, 0.02$. Before autoclaving, the $\mathrm{pH}$ was adjusted to 7.5 and a carbon source $(0.2 \%, \mathrm{w} / \mathrm{v})$ was added. Bacteria were usually cultivated in Erlenmeyer or Fernbach flasks on a rotary shaker at $37{ }^{\circ} \mathrm{C}$, but some experiments were also done in a Biotec laboratory fermenter, model FL 103 (Biotec AB, Stockholm, Sweden).

Agars and agar derivatives. Unless otherwise stated, Difco Bacto-agar was used in most growth experiments. The substrates used for enzyme assays were agarose B grade (lot 90I652 from Calbiochem) and Sepharose beads (Pharmacia Fine Chemicals, Uppsala, Sweden). Samples of alkali-treated agar, epichlorohydrin cross-linked desulphated agar (ECD-agar), and divinylsulphone (DVS), dibromopropanol (DBP) and epichlorohydrin (ECD) cross-linked agaroses were obtained from this Institute (Porath, Janson \& Låås, I97I).

Determination of bacterial growth and residual agar in cultures. The protein content of culture samples was determined by the method of Lowry, Rosebrough, Farr \& Randall (I95I) with bovine serum albumin as standard. Agar was analysed by the orcinol-sulphuric acid method (Svennerholm, 1956) with galactose as standard.

Disintegration of bacteria. Bacteria harvested by centrifuging were mixed in a plastic centrifuge tube with one volume of $0.1 \mathrm{~mm}$ glass beads and about two volumes of $\mathrm{O}^{\mathrm{I}} \mathrm{I} \mathrm{M}$ Hepes buffer $\mathrm{pH} 7 \cdot 0$ (Sigma). The tube was immersed in ice water and its contents were mixed at 6000 to $7000 \mathrm{rev}$./min with a loop-shaped stirrer of stainless steel. This treatment disrupted the bacteria in $2 \mathrm{~min}$.

Assays of enzyme activities. The formation of reducing sugar from agar and agarose was determined with dinitrosalicylic acid (DNS) reagent according to the procedure of Miller, Blum, Glennon \& Barton (1960). Assays on agarose solutions were routinely carried out at $42{ }^{\circ} \mathrm{C}$ by mixing $50 \mu$ lenzyme with $0.45 \mathrm{ml}$ of $0.8 \%$ agarose dissolved by boiling in $0.05 \mathrm{M}$-Hepes buffer $\mathrm{pH} 7.0$. The reaction was stopped after $30 \mathrm{~min}$ by addition of $3 \mathrm{ml} \mathrm{DNS}$ reagent. The samples were then boiled for $15 \mathrm{~min}$, cooled, and centrifuged to remove gel residues. The absorbance was read at $640 \mathrm{~nm}$ and values for reducing sugar were expressed as galactose equivalents. One unit of agarase activity corresponds to the formation of I $\mu \mathrm{mol}$ galactose equivalent $/ \mathrm{min}$.

Agarase activity was also tested with a coloured agarose derivative which was prepared by reacting an amount of Sepharose $4 \mathrm{~B}$ corresponding to $2 \mathrm{~g}$ dry weight with $0.2 \mathrm{~g}$ Cibacronblau $3 \mathrm{G}-\mathrm{A}$ (Ciba-Geigy, Basel, Switzerland) in $0.05 \mathrm{M}-\mathrm{NaOH}$ for $64 \mathrm{~h}$. Dye which had not been bound covalently to the agar was washed away, and the blue product was suspended in $0.05 \mathrm{M}$-Hepes buffer $\mathrm{pH} 7.5$. 


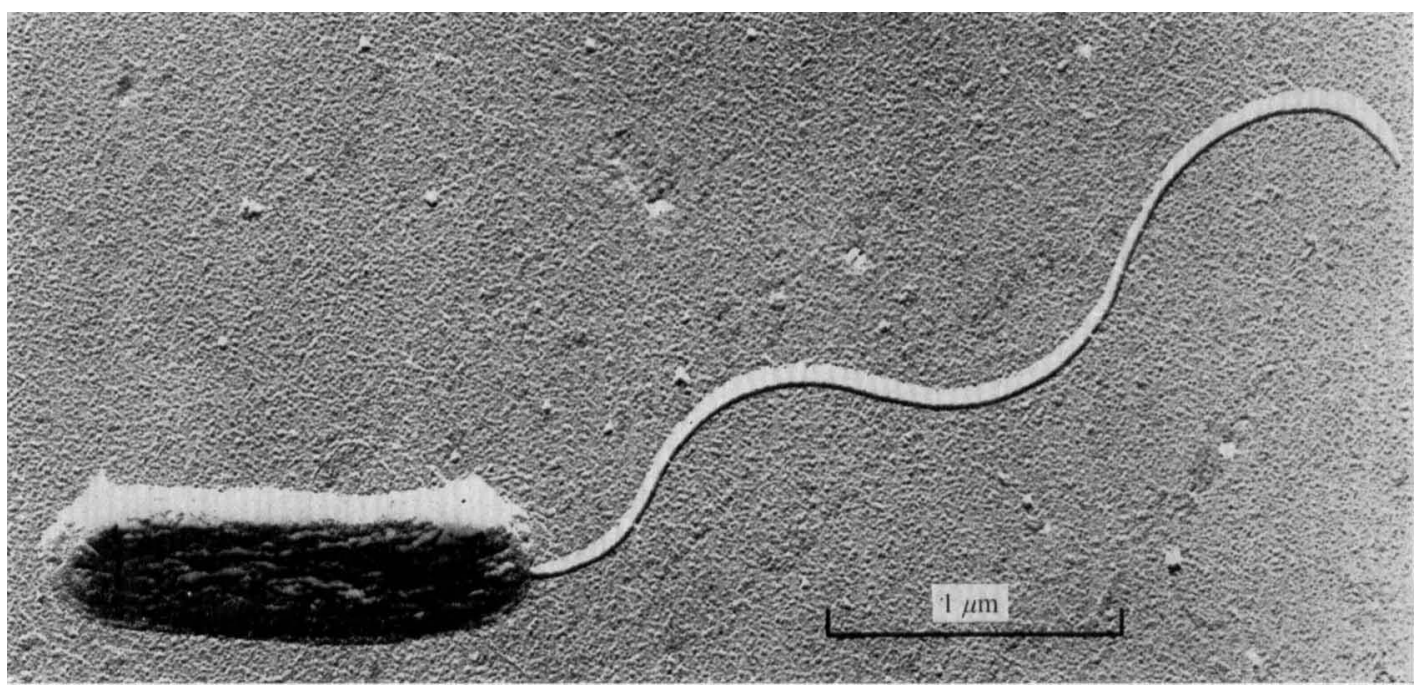

Fig. I. Electron micrograph of the agar-degrading bacterium.

\section{RESULTS}

General characteristics of the bacterium

The agar-degrading bacterium is a Gram-negative, straight or slightly curved rod with a single polar flagellum (Fig. I). It is strictly aerobic and can grow at temperatures of up to $37{ }^{\circ} \mathrm{C}$.

Several carbohydrates were utilized by the bacterium, but it was particularly effective in degrading agar, and growth started more rapidly on $0.2 \%$ agar than on either galactose or glucose. Maltose, lactose and L-arabinose were utilized as carbon sources but not glycerol, mannose, starch or cellulose. No growth factors were required, and the rate of growth was not increased by peptones or yeast extract. The bacterium tolerated somewhat higher concentrations of salts than those of medium B, but phosphate concentrations above $0.1 \%$ caused slow growth. No growth was obtained at a $\mathrm{NaCl}$ concentration above $2 \%$. Growth on nitrate as a source of nitrogen was accompanied by increased $\mathrm{pH}$, but the bacteria grew well in the $\mathrm{pH}$ region $7 \cdot 0$ to 8.5 . When ammonium salts were utilized, the $\mathrm{pH}$ dropped below 7 and growth was slow.

\section{Growth on agar plates}

When the bacteria were streaked on plates with nutrient agar or medium B solidified with $\mathrm{I} \cdot 5 \%$ agar and grown at $37{ }^{\circ} \mathrm{C}$, deep holes were formed by the colonies. Figure 2 shows a plate with such holes caused by dissolution of the agar. After about $24 \mathrm{~h}$ distinct depressions were formed in the agar around colonies, and when such plates were incubated another $24 \mathrm{~h}$ and then flooded with $\mathrm{I}_{2}-\mathrm{KI}$ solution, clear haloes were formed around colonies in contrast to the rest of the plate which was coloured purple brown (Fig. 3). This shows that agarase diffuses out from the colonies, and that the properties of the gel are changed before it is degraded by the bacteria. 


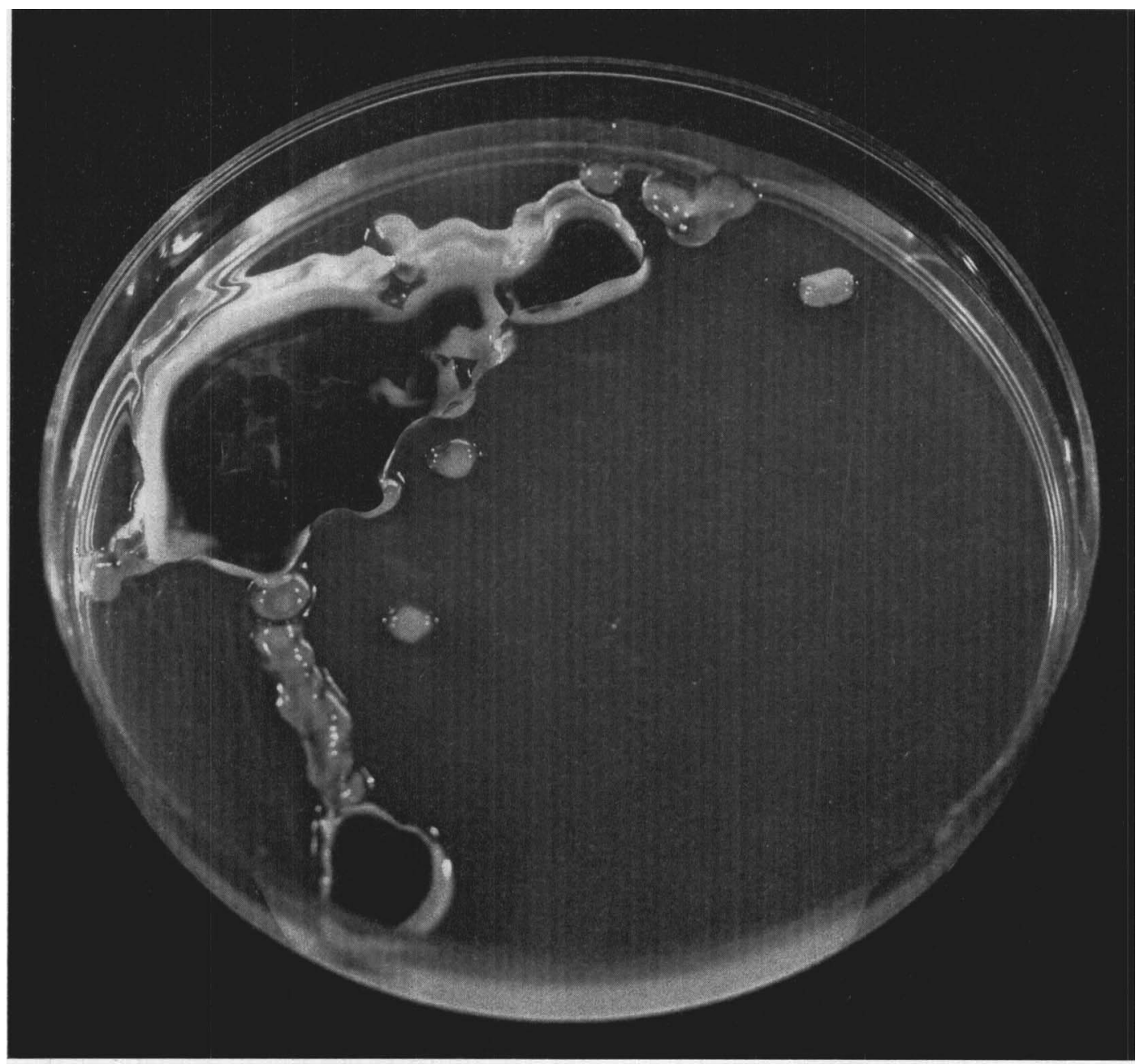

Fig. 2. Growth of the bacterium on an agar plate.

Growth in agar suspensions

Bacteria were grown in medium B with $0.2 \%$ Difco agar, and enzyme activities were determined before and after centrifuging culture samples (Fig. 4). Determination of the amount of carbohydrate left in the medium by the orcinol method showed that more than $80 \%$ of the agar had been used by the bacteria at the stationary phase of growth.

Good growth was obtained in shaken flasks containing semi-solid $(0.5 \%)$ agar, but it took two days before all the gel aggregates had been degraded. More rapid growth was obtained when the autoclaved medium was inoculated with a few millilitres of a culture at a temperature at which gelling would occur $\left(40\right.$ to $\left.45^{\circ} \mathrm{C}\right)$. Agarase present in the inoculum then prevented the formation of a gel.

Cultures were also grown in a Biotec laboratory fermenter and rapid growth was obtained when this was inoculated at $40^{\circ} \mathrm{C}$ and subsequent growth took place at $37^{\circ} \mathrm{C}$. Some foaming occurred, but it could be controlled by the addition of Polyglycol 2000 (Dow Chemical Co., Midland, Michigan, U.S.A.). One experiment was carried out with 


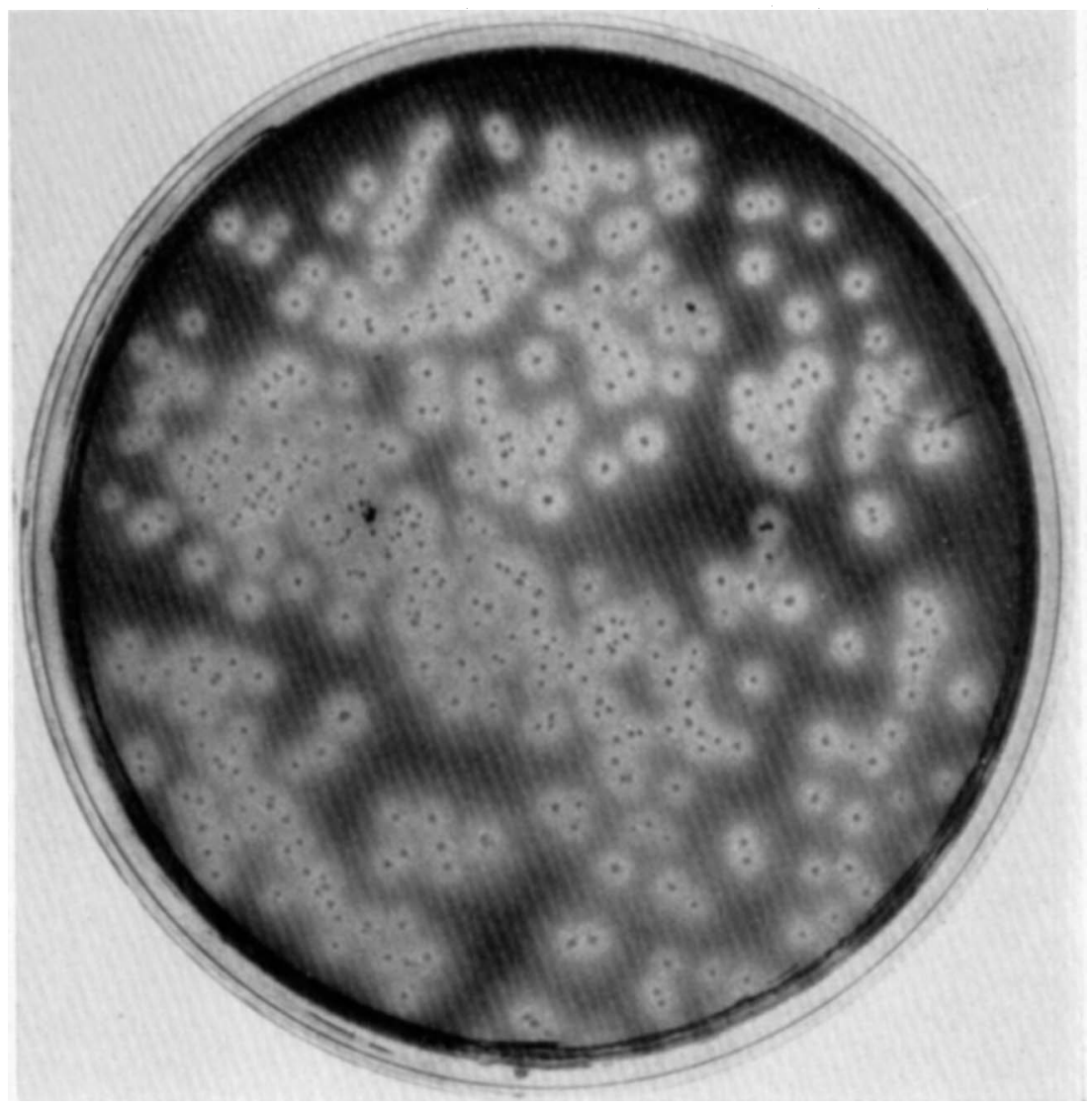

Fig. 3. An agar plate (with small bacterial colonies) flooded with iodine-potassium iodide solution to illustrate the diffusion of extracellular agarase.

automatic addition of $0 . \mathrm{I} \mathrm{M}-\mathrm{HCl}$ to keep the $\mathrm{pH}$ at 7.5 during growth, but no marked effect on the rate of growth and enzyme formation was observed and curves similar to those shown in Fig. 4 were obtained.

\section{Bacterial degradation of different kinds of agar}

Agar and agarose can be modified in different ways to improve their properties for chromatography, electrophoresis and covalent coupling of biological molecules (Porath et al. 197I). We grew the bacterium on different kinds of agar and Table I shows that similar growth yields were obtained. However, there was slightly more growth on the alkali-extracted agar and on Calbiochem agarose than on ordinary agars which contain more sulphur.

Sepharose $2 \mathrm{~B}, 4 \mathrm{~B}$ and $6 \mathrm{~B}$, washed free of the bacteriostatic agent present in the commercial products, were completely degraded after $48 \mathrm{~h}$. Light microscopy showed that the bacteria formed microcolonies on the surface of the beads. At the end of the growth cycle most bacteria occurred as aggregates on the agarose residues.

As shown in Table I, no growth was obtained on two types of cross-linked agars. Samples of several agar derivatives were also enclosed in nylon bags made from $20 \mu \mathrm{m}$ mesh fabric 


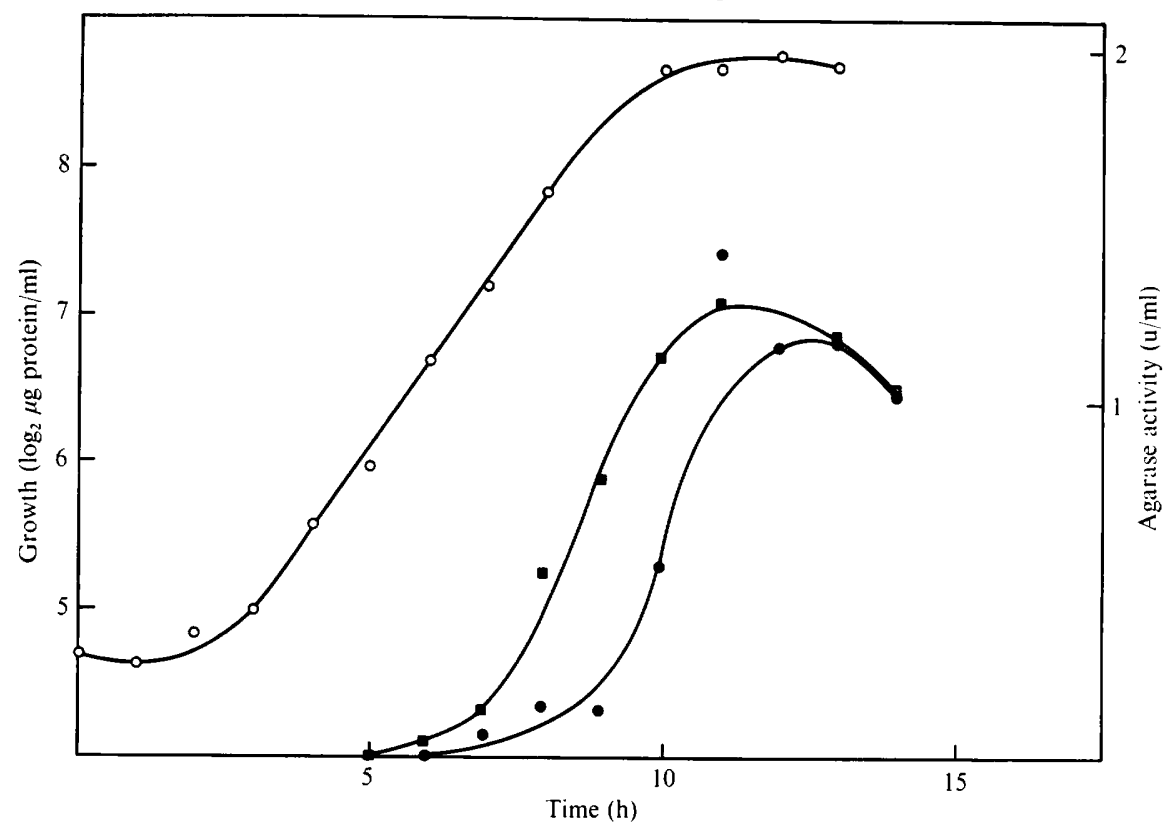

Fig. 4. Growth of the bacterium in medium B with $0.2 \%$ agar and formation of agarase. $O$, Growth $\left(\log _{2} \mu \mathrm{g}\right.$ protein $\left./ \mathrm{ml}\right) ; \boldsymbol{m}$, agarase activity of whole culture samples; $\bullet$, agarase activity of cell-free culture samples.

Table I. Growth of the agar-degrading bacterium on various agars and agar derivatives

Cultures were grown in medium B supplemented with agar or agar derivatives to a final concentration of $0.2 \%$. Cross-linked derivatives were added in the form of beads containing $6 \%$ agar. Growth yields are expressed as mg bacterial protein $/ \mathrm{ml}$ culture after $28 \mathrm{~h}$ incubation when the cultures were in the stationary phase.

$\begin{gathered}\text { Protein } \\ (\mathrm{mg} / \mathrm{ml})\end{gathered}$
$0.5 \mathrm{I}$
0.52
0.58
0.60
0.02
0.02

and incubated in effluent water in the local sewage treatment plant, where the same method has been used to study microbial degradation of cellulose fibres (Hofsten \& Edberg, 1972). The bacterium was isolated from this water and Sepharose beads were completely degraded in bags incubated for two weeks. In contrast, no visible degradation of DVS-agar beads was obtained after five months, and ECD- and DBP-agar beads were only slightly deformed.

We also tried to grow the bacterium on Sepharose to which various enzymes had been coupled by the cyanogen bromide method (Axén, Porath \& Ernback, 1967). No degradation of the beads occurred, probably because the agarose becomes cross-linked when reacted with $\mathrm{BrCN}$.

\section{Degradation of agar by cell extracts and cell-free culture fluids}

As shown in Fig. 4, the agar-hydrolysing activity of cultures is associated with the bacteria during growth, but extracellular enzyme appears in the medium at the end of 


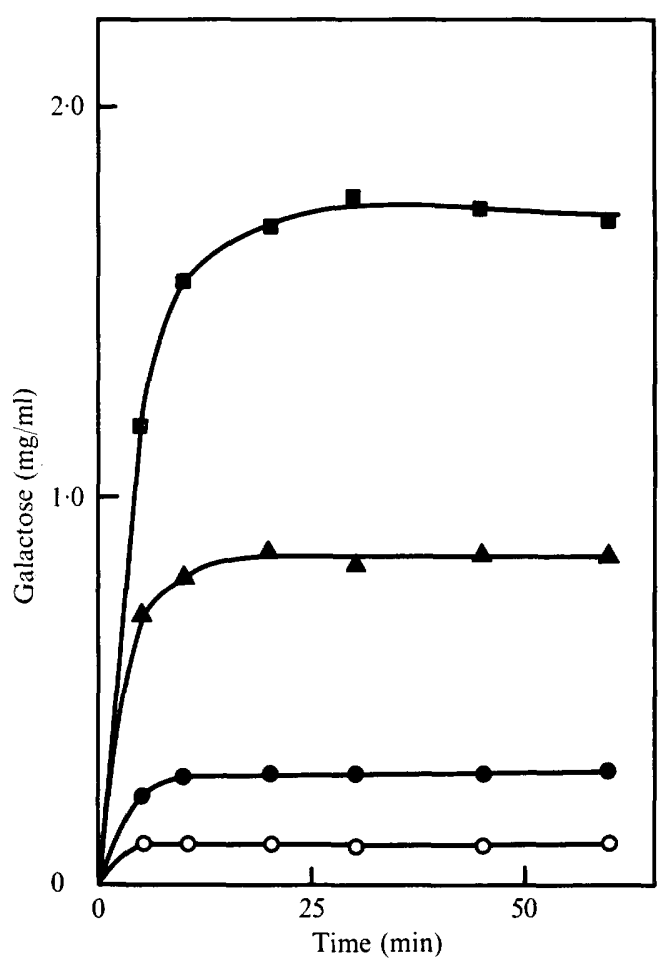

Fig. 5. Hydrolysis of agarose solutions by a concentrated culture filtrate at $42{ }^{\circ} \mathrm{C}$. The reaction was followed by measuring the formation of reducing sugar, expressed as galactose equivalents $/ \mathrm{ml}$. Agarose $(\%): \mathbf{I}, \mathbf{I} ; \mathbf{\Delta}, 0.8 ; 0,0.4 ; 0,0.2$.

a growth cycle on limiting amounts of agar. However, the cells always contained agarase and some experiments were done with cultures which had reached the stationary phase. Sonication did not disintegrate washed cell suspensions, but they were disrupted by treatment with glass beads at high speed as described in Methods. The resulting extract had high agarase activity, and ultracentrifuging at $90000 \mathrm{~g}$ for $45 \mathrm{~min}$ did not decrease the activity. Centrifuged culture fluids could be concentrated about $40-$ fold by ultrafiltration in an Amicon Diaflo cell with PM ro membranes. In the presence of $0.02 \%$ sodium azide, the agarase solutions retained full activity for several weeks at $4{ }^{\circ} \mathrm{C}$ or for several days at $20^{\circ} \mathrm{C}$. The activity was somewhat heat-labile, since incubation at $42{ }^{\circ} \mathrm{C}$ caused a $50 \%$ reduction in activity after $2.5 \mathrm{~h}$.

Addition of cell extracts or concentrated culture fluids to agarose solutions rapidly destroyed the gel-forming ability. Assays with the DNS reagent showed that only about I0 \% of the agarose was hydrolysed to reducing sugars at substrate concentrations from 0.2 to $\mathrm{I} \cdot 6 \%$ (Fig. 5 ).

Pieces of I to $2 \%$ agar gels could be incubated at $37{ }^{\circ} \mathrm{C}$ for several days in culture fluids without dissolution. Some reducing sugar was released during the incubations, but the amount corresponded to only 4 to $5 \%$ of the galactose present in the gels. The effect against blue Sepharose gel was also very slight, and only traces of colour were released. In contrast, solutions of blue Sepharose were hydrolysed and the released colour remained in solution after centrifuging. 


\section{DISCUSSION}

Many agar-degrading bacteria have been recognized since 1902 when Gram isolated the first species from waters off the Norwegian coast. Most strains are marine and require relatively high salt concentrations for growth, but several non-marine species have also been isolated (Araki \& Arai, 1954). The bacterium which we isolated from a sewage treatment plant belongs to the latter category, and it is not surprising that it thrives there, because hospitals, research institutes and a pharmaceutical industry discharge large amounts of agar into the sewage system.

The bacterium has several characteristics of the genus Pseudomonas, but further studies are needed to establish its exact taxonomic position. The two main groups of the genus Pseudomonas have a guanine-cytosine (GC) content of 58 to $65 \mathrm{~mol} \%$, but the value found for this agar-degrading species, $50.5 \mathrm{~mol} \%$, is close to that of the groups III and IV defined by Shewan, Hobbs \& Hodgkiss (I960). Baumann, Baumann, Mandel \& Allen (I972) proposed that bacteria with a GC content of 42 to $48 \mathrm{~mol} \%$, previously classified as Pseudomonas species, should be called Alteromonas. Our bacterium has $50.5 \mathrm{~mol} \%$ GC, which is too high for Alteromonas and too low for Pseudomonas. Further work is being carried out at Torry Research Station in an attempt to classify the bacterium.

Most agar-degrading bacteria grow relatively slowly in comparison with our bacterium which had a doubling time of about $2 \mathrm{~h}$ at $37^{\circ} \mathrm{C}$ on $0.2 \%$ agar in a simple salts medium. During exponential growth the agarase was associated with the bacteria, but almost all of the enzyme activity occurred in the medium at the end of a growth cycle. Microscopic observations showed that the bacteria grew on the surface of agar beads, and it is likely that agar degradation occurs as the result of direct contact between the cells and the substrate.

Several enzymes of different specificity are necessary if agar is to be hydrolysed to its constituent sugars. The initial hydrolytic step appears in most cases to be cleavage of internal $\beta$-(I,4)-linkages between D-galactose and 3,6-anhydro-L-galactose (Araki \& Arai, 1956; Duckworth \& Yaphe, I97I $b$ ). Therefore endo-type enzymes which catalyse this reaction rapidly decrease the viscosity of agar solutions. Further hydrolysis of the neoagarosaccharides and related substituted sugars may then be carried out by exo-type enzymes. $\alpha$-Galactosidases may finally contribute to the complete breakdown of the substrate.

The recent work of Duckworth \& Yaphe (I97I $b$ ) and of Izumi (I972) has shown that the earlier concept that agar is composed of only the two polysaccharides agarose and agaropectin is an oversimplification.

Polysaccharide gels are considered to be composed of three-dimensional networks involving double helical associations between more or less substituted polysaccharide chains of high molecular weight (Rees, I972). Even a few breaks in these chains may interfere with the formation of stable gels. This is probably the reason why agar solutions rapidly lose the ability to gel after incubation with agarase. Some breaks in a gel matrix are also caused by enzyme solutions, and the turbidity of the gel decreases. The unstained haloes around colonies on agar plates treated with iodine show that the properties of the gel had been changed by the action of agarase diffusing out from the bacteria. The binding of iodine to agar gels to give a coloured complex depends on the structure of the gel matrix, but the nature of the binding is not yet known (Ng Ying Kin \& Yaphe, 1972).

We cannot explain why living bacteria are more effective in degrading agar gels than are agarase solutions. The bacteria have a very high enzyme concentration on their 
surface, and it is possible that this is a sufficient condition for effective gel degradation. Their ability to move on the gel matrix and align the enzyme molecules so as to enhance their interaction with the polysaccharide may also be important.

Agar and agarose derivatives used for chomatography and as supports for immobilization of various biological molecules are often prepared by procedures which cause cross-links within the agar beads. Our finding that such cross-linked gels were resistant to degradation by the bacterium and even withstood exposure to sewage effluent for several months shows that the cross-links impose a high degree of biological stability to the agar. Since the cross-linked agar beads have better flow properties and higher mechanical stability, they represent a great improvement over ordinary agarose beads which are much less stable.

We thank Dr J. M. Shewan and Dr D. M. Gibson, Torry Research Station, Aberdeen, for $\mathrm{GC}$ analysis and for valuable discussions on the taxonomic position of the bacterium. We also thank Mr W. Hodgkiss for taking the electron micrograph.

\section{REFERENCES}

AraKi, C. \& AraI, K. (1954). Studies on agar-digesting bacteria. The isolation of agar-digesting bacteria and their enzymatic activities. Memoirs of the Faculty of Industrial Arts, Kyoto Technical University, Science and Technology $3 \mathrm{~B}, 7-23$.

Araki, C. \& AraI, K. (1956). Studies on the chemical constitution of agar-agar. XVIII. Isolation of a new crystalline disaccharide by enzymatic hydrolysis of agar-agar. Bulletin of the Chemical Society of Japan 29(3), 339-345.

Axén, R., Porath, J. \& Ernback, S. (1967). Chemical coupling of proteins to agarose. Nature, London 2I5, I 49 I-I 492.

Baumann, L., Baumann, P., Mandel, M. \& Allen, R. D. (1972). Taxonomy of aerobic marine eubacteria. Journal of Bacteriology I10, 402-429.

DuckwORTH, M. \& YAPHE, W. (I97I $a$ ). The structure of agar. I. Fractionation of a complex mixture of polysaccharides. Carbohydrate Research 16, I89-197.

DUCKWORTH, M. \& YAPHE, W. (I97I $b$ ). The structure of agar. II. The use of a bacterial agarase to elucidate structural features of the charged polysaccharides in agar. Carbohydrate Research r6, 435-445.

v. Hofsten, B. \& EDberG, N. (1972). Estimating the rate of degradation of cellulose fibers in water. Oikos 23, 29-34.

IzUmI, K. (1972). Chemical heterogeneity of the agar from Gracilaria verrucosa. Journal of Biochemistry 72, I35-I40.

Lowry, O. H., Rosebrough, N. J., Farr, A. L. \& Randall, R. J. (I95I). Protein measurement with the Folin phenol reagent. Journal of Biological Chemistry 193, 265-275.

Miller, J., Blum, R., Glennon, W. E. \& Barton, A. L. (1960). Measurement of carboxylmethyl cellulase activity. Analytical Biochemistry $\mathbf{I}, 127^{-1} 32$.

NG Ying KIN, N. M. K. \& YAPHE, W. (I972). Properties of agar. Parameters affecting gel formation and the agarose-iodine reaction. Carbohydrate Research 25, 379-385.

Porath, J., JANSON, J.-C. \& LÅÅS, T. (197I). Agar derivatives for chromatography, electrophoresis and gel-bound enzymes. I. Desulphated and reduced cross-linked agar and agarose in spherical bead form. Journal of Chromatography 60, I67-177.

REES, D. A. (1972). Shapely polysaccharides. Biochemical Journal 126, 257-272.

Sampietro, A. R. \& Vattuone de Sampietro, M. A. (I97I). Characterization of the agarolytic system of Agarbacterium pastinator. Biochimica et biophysica acta 244, 65-76.

Shewan, J. M., HobBs, G. \& Hodgkiss, W. (1960). A determinative scheme for the identification of certain genera of Gram-negative bacteria, with special reference to the Pseudomonadaceae. Journal of Applied Bacteriology 23, 379-390.

SvenNerholm, L. (1956). The quantitative estimation of cerebrosides in nervous tissues. Journal of Neurochemistry $\mathbf{I}, 42-53$. 